\title{
Logics of Action and Associative Experiences in Public Action for HIVIAIDS Control: Case of AAS and REVS+ in Burkina Faso
}

\author{
Kamba André-Marie Soubeiga \\ Laboratory for Interdisciplinary Research in social Sciences and Health (LARISS), Department of Sociology, University of Ouaga1, \\ Pr Joseph-KiZerbo, Ouagadougou, 03 BP 7021, Burkina Faso
}

\begin{abstract}
The late 1990s was a significant landmark in HIV control all over the world and more particularly in Africa and Burkina Faso. Right from the outset in this country, the critical measures that public authorities and their international partners took against $\mathrm{HIV}$, indeed encompassed associations which became the mainspring in the national incentive. Hence, the emergence of associations in the bid to contain AIDS which was initiated and gathered momentum in the decade from 1990 to 2000. The key target of these NGOs (non-governmental organizations) and associations was to attend to HIV patients considered as being most vulnerable to this infection. As a consequence, their main challenge was to put forth specific initiatives to meet their numerous needs. The manifold implications stemming from assisting infected people (prophylaxis, treatment, psychological counselling and so on) alongside collective management in an environment streamlined by the government and international financial backers are indications of an ever-growing complexification of public action requiring from the associations an adaption to the process as well as seasonable responses. Being the much sought-after health partners, the social organizations display their social efficiency in the general interest. This research deals with the experience of two pioneering health partners (AAS and REVS+) that, as early as 1998, broke grounds in treating HIV patients long before the government made the move to use ARV and many other methods. It hinges upon field observation and sound interviews with the staff and members of these associations in Ouagadougou and Bobo-Dioulasso.
\end{abstract}

Key words: Associations, public action, HIV/AIDS, vulnerable people, Burkina Faso.

\section{Introduction and Context}

In Burkina Faso, the first national AIDS control initiatives were conducted, from 1990-1991, by government organizations, in partnership with INGOs (International Non Governmental Organizations) and supported by the partners of the bilateral and multilateral cooperation [1]. AIDS being above all a "political epidemic" [2], then an unprecedented experiment of joint construction of a public action was set up between, on the one hand, the Government of Burkina Faso and, on the other hand, organizations of the civil society [3]. Among the INGOs that were at the forefront in this AIDS crusade, the most prominent

Corresponding author: André Soubeiga, $\mathrm{PhD}$, professor, research fields: medical sociology and anthropology. were the Social Condom Marketing Project (PROMACO) and PSI ${ }^{1}$. These two INGOs have actually been established under the supervision of the National Committee for HIV/AIDS control, but as autonomous organizations financed by USAID. PROMACO, in particular, will take over from the Information-Education-Communication sub-committee of the Ministry of Health, by giving national prominence to condom promotion efforts in Burkina Faso.

Thus, in the early 1990s, in collaboration with the National Council for AIDS and STIs control (CNLS-IST), PROMACO will promote the first ever

\footnotetext{
${ }^{1}$ PROMACO benefitted from the technical support of Population Service International (PSI), a pioneer NGO in the social marketing of contraceptives.
} 
mass campaigns. The aim was to organize the distribution and extension of condoms use as part of HIV/AIDS prevention. The project uses conventional marketing methods to make condoms ${ }^{2}$ accessible and affordable (financially) and to convince people of the necessity to use them to protect themselves against HIV infection. In the communication strategies favoured by PROMACO, the "Information, Education and Communication" (IEC) component was particularly important: promotion of information campaigns in different groups and sectors of society (truck drivers, schools, prostitutes, as well as in the general population), distribution of condoms at "social" prices $^{3}$, without forgetting the development and provision of teaching aids, etc. [4].

The sudden emergence and then the rooting of the NGOs/associations in the AIDS control in Burkina Faso are a structuring element of this fight which contributed, in a certain way, to redesigning its outlines and its stakes. Shy and unusual at the outset, the multifaceted mobilizations and commitments of the associations and the community are now part of the key moments of this fight, devoting, for some time, NGOs/associations as pillars of the national response to AIDS. As a result, the associations have gradually been built up and structured, benefiting from the "boost" from Northern agencies and NGOs, including local actors from biomedical circles [5, 6]. By positioning itself in this fight arena, the associative movement has contributed to giving another look to the public action by means of local actions, mainly for the benefit of the underprivileged [7].

Today, however, the impact of HIV among the general population seems more and more "negligible”. Indeed, since 2013 in Burkina Faso, the national prevalence rate of HIV infection is estimated at $0.92 \%$. But this "performance" conceals huge disparities. In

\footnotetext{
${ }^{2}$ With the promotion of a brand named "Prudence".

3 After acting for nine months, this organization was said to have sold more than 5,500,000 Prudence condoms. cf. J. Vallin (ed.). 1994. Populations africaines et sida. Paris: La Découverte/CEPED, p. 201.
}

the sub-category "sex workers" it is about $16 \%$ and quite above the national average ${ }^{4}$ for all the other categories of sub-populations. Current awareness raising and care strategies are redirected primarily (but not exclusively) to these "key populations" ${ }^{5}$ who, according to public policy makers, can be vectors for the rebound of the epidemic, if nothing is done to insert them into the screening and care circuits.

The aim of this research is to take into account the circumstances that led to the involvement of the associative organizations in AIDS field and to decipher the meaning and the motivations (social, political) that underlie the investment of the associations in the conduct of the public action for the benefit of people facing social suffering. It should be noted, however, that the study focuses more on the strategies deployed by the associations to strengthen their operational capacities than on their target audiences ${ }^{6}$.

The sociology of public action and public policies will be used here as a theoretical framework for reflection on associative action as an interactive process involving a plurality of actors. Indeed, any analysis of public policies is confronted, in some way, with the multiplicity of actors involved in their development and implementation: organized groups, media, political actors, government actors, administrative actors, "Public opinion”, etc. But in the present case, it is really a question of getting out of the "stato-centrism" of the policy sciences, with pre-eminence to the government action. In addition to this long-standing "stato-centred" approach in the industrialized countries, a broader vision was developed, which assumes that many actors (public, private, associative), at different spatial scales, participate in the formulation and the

\footnotetext{
${ }^{4}$ According to information given during the $8 \mathrm{pm}$ television news (RTB) on December 15, 2015.

${ }^{5}$ Men who have sex with other men, sex workers, gold miners, etc.

${ }^{6}$ Indeed, in the sociological and anthropological literature, much work has been largely devoted to prevention, care and social and psychological support for people living with HIV, as a target audience for these associations. On the other hand, the analysis of associative action under the prism of the sociology of public action still remains to be constructed.
} 
implementation of public policies. The government thus has its monopoly of intervention in the public space challenged, with the more and more manifest participation and commitment of private actors and associations in public arenas. The public action can then be considered as the outcome of complex processes of confrontation, negotiation, as well as the compromise among various actors.

The implementation of policies in AIDS field in Burkina Faso can be viewed in the same way. The conduct of public policies in AIDS field was initiated with the Government which as the main actor and the authorizing officer. Indeed, the central authorities seemed to have the power and the legitimacy to design, guide and decide on the strategies to fight against AIDS. At the same time, the Government, because of its "fragile" nature and its dependence on external funding, could hardly be the only one to fight against AIDS and monopolize the monopoly of the legitimacy of this fight. In other words, they will be forced to deal with a variety of actors whose emergence, maintenance and legitimacy on the public scene, have been steadily reinforced as AIDS epidemic spreads. The field of public action is ultimately revealed as a configuration of interacting actors in which the Government and the associations find their place. Such a concept refers more precisely to an approach of public action rather than public policy. In other words, it means that the former is not reduced to the latter, but on the contrary encompasses it and that "the exercise of power is seen only through reforms, but also in the 'ongoing' action” [11].

It therefore seems pertinent to us to favour an "extensive" meaning of public action, which is not limited to a strictly institutional definition [8, 9]. Public action cannot be limited to action by or on behalf of State agents alone. On the contrary, it must be thought and conceived as an action that "opens up, overflows from its only conventional and institutional definition, into other spaces, and becomes embedded in other logics....” [10]. However, the articulation to a public space is undoubtedly an element to be taken into consideration, in order to better know in this open field, "where public action begin and ends"! As Dourlens says, it is more the quality of the space on which public action is deployed that can make it "public". Therefore, to deserve this attribute, we should expect public action to take place on the stage of the public stage and where public actors and events and social problems gain access to public visibility [10].

In the model of construction of the public action against AIDS in Burkina Faso, the Government won fame through their initiatives during the first four years of the struggle (1987-1990) thanks to the support of their international partners. The co-constructed aspect of this public action gained gradually visibility when NGOs and associations entered the scene (decade 1990). From 2001, a new step will be taken with the affirmation of the multi-sector nature of the fight with a greater implication and responsibility of the different components of the society. We will even end up, with the opening of voluntary screening centres under the instigation of some associations, and a few years later with the proliferation of the centres of treatment with ARVs, with a decentralization of the process of medical and psychosocial care for the patient. This model is ultimately a multi-stakeholder and multi-level public action where, the Government is joined by actors from other spheres of society (associations, private), determined to take an active part in the management of collective problems.

The empirical data used to support the analyses developed here, were collected between 2013 and 2015 from leaders of AIDS associations in Ouagadougou and Bobo-Dioulasso (managers and/or their close associates), as well as the Permanent Secretariat of the National Council for the Fight Against Aids and STIs (SP-CNLS) and PAMAC ${ }^{7}$, a dozen of interviews, some of which were repeated in order to gather more in-depth mentioned themes (focused on aspects related

\footnotetext{
${ }^{7}$ Program of Support to the Associative and Community World.
} 
to the creation of the association, its objectives, its means of action, its organization, actions and partnership, achievements and difficulties and future prospects). The semi-structured interviews with these informants were supplemented by observations made in the care centres of some associations (AAS, ALAVI $^{8}$, REVS+, CIC-doc) ${ }^{9}$. The empirical corpus thus obtained was the subject of analyses of the thematic content of talks and life stories, notably with the leaders of AAS and REVS +. For the purposes of the analysis, all the interviews were collected on a Dictaphone and transcribed into text before exploitation.

\section{The Rooting of Pioneer Associations in the Fight against AIDS in Local Arenas}

At the beginning of the 1990s, public action against AIDS started extending and began to make an impression. In addition to the international organizations that have come to support the health authorities, the creation of Burkina Faso's first association for AIDS control, albeit without media coverage, will foreshadow the direction of this struggle for the rest of the decade. AAS and REVS+ are currently two AIDS service organizations with many similarities in their respective status and in the conduct of their activities. However, their story and their routes differ in many ways. In view of these considerations, many associations involved in the fight against AIDS could have been selected here. However, the illustration through the experiences of these two organizations aims to highlight the singular contribution of each of them to the better living for the HIV positive people (vulnerable people par excellence) at a crucial time of the pandemic spread. The example of these associations also highlights two distinct situations which, at a given moment, led to their appearance in the public space for HIV/AIDS

\footnotetext{
${ }^{8}$ Laafi La Viim Association ("Health is life", in Mooré, a national language).

9 Information and Documentation Centre on AIDS and Sexually Transmitted Infections.
}

control.

\subsection{AAS: A Pioneering Organization and Advocate of} the Struggle for Access to Information for the Public

The Association African Solidarity (AAS), founded in 1991 in Burkina Faso, is now an organization committed to fighting AIDS as a national NGO. It aims to contribute to the socio-economic integration of young people and the fight against major pandemics. In 1993, it initiated its first awareness-raising activities on HIV/AIDS first in Ouagadougou then in other areas like Djibo, Ouahigouya, Garango, Tikare, etc. Since its appearance an association in Burkina Faso, AAS intervenes mainly in the STIs/HIV prevention, counselling, care providing for HIV positive people. In 1998, just when the epidemic reached its peak in Burkina Faso, it founded its first centre of comprehensive care for people living with HIV/AIDS: the "Oasis Centre" the vocation of which is to contribute to improving the quality of life of people living with HIV/AIDS by providing a continuum of care that combines medical and community care. The package of "community" activities includes moral support, end-of-life support, support for return to work, and economic reintegration. Through these forms of assistance and support, the NGO intended to help restore the image and dignity of PLHIV by offering them opportunities to lead a normal social life. The Oasis centre, which originally intended to provide care to some 50 people, is currently monitoring more than 3,800 people living with HIV, of whom 1,600 are currently on ARV treatment.

At the national level, the NGO receives help from the Ministry of Health (ARV, reagents, etc.) and SP/CNLS. At the international level, its main partner for several years has been Sidaction, whose multifaceted assistance contributes significantly to the improvement of its operation ${ }^{10}$.

\footnotetext{
10 Among the other international partners there were the Fondation France, UNICEF (for activities focused on infected or affected children), WFP (Food Supplements for PLHIV), the Total Foundation, the World Bank, etc.
} 
"There are partners who take into account our needs, I want to talk about Sidaction, for example, which, beyond funding for care, takes into account our purely institutional needs; this partner is supports us to evolve at the moment... Accounting uses accounting management software with their support. So the accountants have been trained and all the financial management of all the partners is done with this software. They also supported us to certify our 2012 accounts and coach us for the certification of 2013 accounts to be done this week or next week, and in the second semester it will be the certification of 2014 accounts; so that is a partner who does not take into account... only what they give... but they also thinks of supporting us to go forward" (interview, coordinator of the Oasis centre, May 2015).

Today, AAS is as a remarkably structured NGO, with some 100 staff (permanent and temporary) involved in the implementation of its activities in five cities in Burkina Faso ${ }^{11}$.

Today, this NGO has implemented in the field different intervention strategies necessary and adapted to the proper functioning of a "community" organization, without overlooking the necessity to rationalize its operating mode. In this perspective, it has developed frameworks and appropriate equipment for the implementation of the activities it intends to promote. To this end, it has given itself the means to hire a multidisciplinary and polyvalent staff of specialists (doctors, pharmacists, nurses, psychologists, laboratory technicians, lawyers, and social agents), who contribute, each according to his/her field and his skills, to the achievement of the overall objectives of the NGO. The recipients of AAS actions are not just beneficiaries (apart from orphans and vulnerable children); they can also be involved in the definition and implementation of activities, in line with the philosophy they claim to adhere to [12].

\subsection{REVS+: An Association That Advocates Right Away to Prioritize Medical Care}

11 They are Ouagadougou, Zorgho, Koupela, Cinkensé, Zingari.
The NGO named REVS+ is defined as a "community-based, apolitical, non-denominational non-profit making organization”. Appeared on the public scene in 1997 and officially recognized in February 1998, it brings together people infected and affected by HIV, and at the same time appears as an "association of people living with HIV". In 2004, it was a national NGO. Its main mission is to help improve the living conditions of people living with HIV. Since its creation, REVS+, like AAS, relies on an intervention strategy based on beneficiary participation and its actions are mainly focused on the prevention and care (psychological, social and medical) for patients and persons infected with HIV.

One of the main objectives of REVS+ is to improve the living conditions of people who are infected and living with HIV by facilitating access to information, screening, as well as a comprehensive care, combining a community approach and a medical approach. This ambition is in line with the preoccupations of the moment, where the issue of the medical care for PLHIV is acute. It has more recently extended its services to specific target populations such as orphans and vulnerable children (OVC), "Because we used to receive and suddenly we were confronted with the child born to HIV-positive parents and sometimes HIV positive. So we have an OVC program, called the 'growing up with HIV' program (interview with the President, September 2015).” More recently, another key approach to care for key populations has been developed: sex workers and sexual minorities, especially "men who have sex with men.” They were specifically provided with a package of services, from screening to access to care, including advocacy for the recognition of their social rights. In the course of its evolution, the association has gradually decentralized its activities and is currently represented in three regions of Burkina, with branches in five provinces ${ }^{12}$,

12 These are Bougouriba province in Diébougou, Ioba in Dano, Tuy in Houndé, Banwa in Solenzo and Mouhoun in Dédougou. The provincial branches do not offer medical consultation activities, but work in partnership with the health centres. 
in addition to the city of Bobo-Dioulasso. REVS+ finally has a medical centre that works as a day hospital. The follow-up of PLHIV, in June 2015, listed 2,850 people, of whom almost 2,000 were women, 1,266 people are on ARVs, including 866 women [13]. These associations "from the beginning" all have in common the fact that they were at the time of their appearance, weakly structured and without great means of action. Their activities were exclusively focused on awareness-raising (prevention tips, condom distribution and demonstration of condom use), exclusively in confined spaces such as within their headquarters ${ }^{13}$. Only NGOs such as PROMACO/PSI and the "Union Burkinabé de Lutte contre le Sida" (Union for AIDS Control of Burkina Faso, URBLS) were conspicuously present on the public sphere for their mass awareness raising activities. It is in such a context that the first publicized testimonies of people announcing their HIV status on the national television would take place in $1997^{14}$.

This "audacity to break"15 (with a long tradition of concealing the infection due to stigmatization) has been largely inspired and driven by the experience of the testimony of infected people in the North who have publicly confessed their HIV status. Moreover, many PLHIV associations that emerged in Burkina Faso in the 1990s (and even later) benefited from the support and/or assistance of external partners (case of AAS, ALAVI, REVS+, URBLS supported by Sidaction, or by the French Association of Volunteers of Progress). This joint venture, involving local actors, international actors and PLHIV, will have the effect of propelling on the public scene of Burkina Faso, "new" actors and a new way of tackling AIDS. AIDS has thus become the first case (in the health field) with the mobilization and

\footnotetext{
${ }^{13}$ With the exception of APRODEC which, with the support of the French Cooperation, is engaged in the promotion and implementation of voluntary screening.

14 For the city of Ouagadougou, it seems that these testimonies were made in Bobo-Dioulasso, much earlier, in 1996.

15 Expression borrowed from Olanguena Awono U, 2006. AIDS in Africa. The audacity of the breaks, Toulouse, Privat, p. 183.
}

commitment of patients grouped into associations and their inclusion at the heart of public action [5, 6, 12].

\section{The Associative Care Offer: The Long Walk for Access to ARVs}

The first offers of care on ARVs in the context of Burkina Faso, were made by the associations. As soon as ARVs were introduced into the country, associations, through their leaders, were confronted very early with the need to develop strategies to obtain them. This early commitment by associations to offer ARV treatment to their infected members can even be deciphered as a political message to national decision makers about the urgency of making a real ARV access policy. Indeed, "The association relies on the social link to reach the political circle since it builds alliances beyond inter-personality while including it, from a project of action on society, either complementary to Government social interventions, or challenging and working to impose the consideration of new issues" [14]. In this case, the willingness of associations to make ARVs accessible to patients (even on a very small scale initially) contrasts with the supposed apathy of the central authorities. Punctuated with trials and errors, this form of associative action in the distribution of ARVs has been rather long and complex to take place. It took shape previously before the 2000s, shortly after the combination therapies in northern countries were practises (1996). Two years later, these treatments were timidly introduced in developing countries, but accessible only to a tiny minority [15]. At a time when the epidemic was raging for about fifteen years, it was only at the beginning of the 2000s that the first patients in Burkina Faso from popular or underprivileged classes experienced these coveted treatments. These initiatives are the work of two associations (AAS and REVS+) which exploited, each in its own way, often unexpected opportunities to introduce, through their own circuits, ARVs in Burkina Faso.

\subsection{AAS: From the Singular Experience of an Infected Member to Community Outreach}


It seems to be a particularly illustrative willingness shown by the leaders of this organization to make every effort to help some of their infected members to benefit from treatment. In 1997, the first head of the association during an internship mission in Abidjan (Ivory Coast), noted that associations had initiated medical care activities for HIV-positive patients. Back in Ouaga, he tried to sound out the health authorities and other association leaders on the opportunity to experience this idea in Burkina, but he met with reluctance.

However, for AAS, the adventure begins with one of its leaders who was one of the first patients to personally experience ARV treatment in 1997 in France. He used to go there periodically for his follow-up and treatment with his doctor at the Institut Fournier in Paris). He confessed to having received from this doctor a treatment that was proved very promising. Satisfied with this result, the practitioner then suggested his continuing this experience by working with a doctor in Burkina, in order to make other infected people benefit. This partnership is quickly set up with a doctor in Burkina Faso (doctor at the Oasis Centre of AAS, then at the Outpatient Treatment Centre of Ouagadougou) and made the treatment of a dozen people possible ${ }^{16}$. During the same period, the association "METIS" founded by a French doctor living and working in Burkina ${ }^{17}$, also collected some drugs for AAS.

But few people benefited from this privilege of care, which required the association to redouble its efforts to meet a constantly rising demand. In order to circumvent the financial barrier (the costs of ARVs being high and inaccessible), it was necessary to imagine alternative solutions. Two periods can be distinguished in the strategies deployed by the association. At first, AAS will rely on its relational

\footnotetext{
16 This AAS official admitted to having learned later that these drugs that came from France were in fact meant to be destroyed by incineration.

${ }^{17}$ Member of the consultancy and technical support firm called "Ici-santé" in Ouagadougou.
}

capital, leveraging its institutional links with its international partners (Northern NGOs, as well as individuals) to "collect" some ARVs. Its strategy was then to deal with some friendly Associations and NGOs (in France in particular), to get ARVs intended primarily for its infected members. "They-the leaders of AAS-initiated this before the Government even had the means to do it; it was when the ARVs cost 1,000 euros/month (so more than 600,000 FCFA) and this was costly... There were a few people who started these treatments and many have not even finished and died, because it was too expensive..." (interview, CIC-Doc Program Officer).

But this "prowess" achieved by the association was made with sustained effort. At this time, very little was possible or available locally, given the weakness of the technical platforms of most health facilities. Biological examinations, the results of which were essential for measuring viral load and for deciding whether or not to use $\mathrm{ARVs}^{18}$, were provided only in a few laboratories with prices that were inaccessible to most patients. In the absence of available technical means, for AAS, it was necessary to first collect blood samples taken from patients, and then send them to the Europe for the evaluation of the viral load. Once this step was completed, the European NGOs solicited (AIDS, Sidaction, Solidarity AIDS, as well as some individuals) collected the medicines they had in order to send them, free of charge, to AAS. One of the leaders of the ASA admits that these beginnings were difficult, and even admits that there was a lot of trial and error in the medical decisions.

"Initially, when CD4s could not be measured on the spot, to decide to put a person on ARVs ... in fact it was essentially clinical. The doctor was trying to see if there was the possibility of doing examinations in Europe; otherwise, in some cases, the decision to take ARVs was made on the basis of a clinical examination, supported by other tests such as serum creatinine,

\footnotetext{
${ }^{18}$ At this time, before deciding to put a patient on ARV, it was necessary to measure the viral load that is to count the CD4; an operation that was virtually unimplemented at the local level.
} 
blood glucose to take into account certain parameters before including the patient on anti-retroviral treatment. (ART)".

However, when the case was more delicate, and the attending physician absolutely needed to measure the viral load, blood was collected and sent to France.

Knowing that this strategy could not meet a growing demand in the long run, the AAS opted to take advantage of the opportunities offered by its relations at national and international level to advocate for the signature of agreements with partners, some of whom have pledged to support the treatment of a certain number of patients on ARVs. In this perspective, the number of people benefiting from ARVs in the association, a dozen at the beginning has experienced a trend increase as the commitment of partners increased. "It began gradually. To have even a hundred people, it took a few years. Initially in 2002, we had a partner who agreed to take care of 25 people on a regular basis. A second and a third associations respectively took care of 5 and 15 people." (interview, coordinator of the OASIS centre, May 2015). Thus, the Burkina Faso leather and hides company, called Tan Aliz, offered to take care of thirteen people of the association, on ARV for several years. Without minimizing those contributions that have served the ASA well in its fight for the popularization of ARVs, the most impressive advances were nevertheless the agreement signed with the "Orange" project and the collaboration with the Government of Brazil, each of which has helped about two hundred people to benefit from ARV treatment just before the Global Fund support ${ }^{19}$.

Given these facts, regardless of the sector considered (government, medical, religious or community) it

\footnotetext{
19 As part of this collaboration, Burkina Faso and Brazil were state-to-state, but the beneficiary was AAS that had filed a petition with Brazil. At the 14th International Conference on AIDS in Barcelona (July 2002), the chair of AAS participating in it received the information that Brazil was eager to support African countries to increase access to ARVs. He filled in and submitted the application form for this purpose; his request was successful and Burkina was thus selected as a beneficiary country. The ARVs for AAS were channeled through Médecins Sans Frontières, which then handed them over to AAS.
}

appears that AAS was the first organization to offer ARV treatment to people infected with HIV in Burkina, from ARV introduction in Burkina Faso, in 1998. These actions both symbolic and strong, quickly established AAS at the national level as a pioneering association, whose initiatives can be seen as a prefiguration of the future national policy of access to medicines. But before that, they will gain ground and inspire other associations that will, in turn, seek to position themselves to offer care to their HIV-infected members.

\subsection{REVS+: A Voluntary and Determined Action for} Access to ARVs

Unlike AAS, REVS + chooses to advocate at the local level with the customs departments, even if initially it has benefited from drugs (ARV) collected by partner NGOs such as AIDS, Sidaction, Solidarity AIDS, for its members. Its project was to order generic drugs from India to redistribute them free of charge to its infected members ${ }^{20}$. Like some countries such as Brazil and South Africa, India is one of the "emerging" countries that have also started making ARV copies, which should open a window of opportunity for some low-income countries (or even some Southern NGOs) to establish their ARV access policy. As we know, these three countries have long been under the threat of a few pharmaceutical companies, determined to bring a lawsuit against them, for the manufacture of illegal copies of their products still under patent. But the strong international mobilization and the unwavering determination of NGOs and AIDS activists finally forced these major laboratories to abandon their project in 2001 [1]. In doing so, the REVS + association was soon confronted with the problem of product clearance

\footnotetext{
${ }^{20}$ As for the ALAVI Association, the coordinator states that his association started receiving ARVs from northern partners and the products were sent via the Post Office: "We started receiving ARVs from our AIDS partners through DHL to start to initiate the first treatments even though at the national level it was not available and even not accessible, then it became available but not financially accessible because it was very expensive, there were combinations that cost around 600 000FCFA”.
} 
and had to develop a plea with the customs and the SP/CNLS to obtain exemptions by highlighting its NGO status. It has succeeded in making customs of Burkina Faso a "partner" by taking advantage of its new status as a national NGO:

"Our argument was to show that these drugs were not for sale, but to distribute to the needy people to save lives ... And the customs teamed with us, with the contribution of exempting from tax those drugs that we ordered. For 3 to 4 years, we did it and we tried to work with $\mathrm{CAMEG}^{21}$ to refer these addresses to CAMEG since at this time CAMEG was ordering in other areas that were expensive; because if you want the ARV combinations at that time it was expensive. And we had it three times cheaper from India” (interview, President of REVS +).

Of course, the treatments initially obtained from French NGOs were intended for only a handful of people, without any comparison with the number of patients requiring this type of care. Very quickly, the association was overwhelmed by requests. Unable to satisfy everyone, it tried, somehow, to set criteria to retain the most "deserving". So, it tried to prioritize beneficiaries by highlighting the health status of applicants (based on viral load); people with family and family responsibilities were retained (to the detriment of single ones). Age also appeared as another selection criterion (children having more chances than adults). But beyond these criteria, it was above all for REVS + to retain, as a priority, founding and/or active members of the association who, not only had accepted their (HIV-positive) status, but were involved "voluntarily" in assisting others. These members, who were useful in the association, have been systematically included as primary beneficiaries of ARVT. The reason given was that they needed to be kept alive so that they could continue to work for the benefit of others. The leaders

21 The Central Purchasing Center for Essential and Generic Medicines, which is a Government organization responsible for importing and distributing drugs (including generics) in Burkina Faso. Since April 1999 she sells ARVs in Burkina. of the association, however, recognized the somewhat discriminatory nature of these choices, but seemed to have no other way to designate the eligible people for these treatments, synonymous with "keeping alive”. The confessions of the president, quite helpless were revealing this deep embarrassment:

"We should not see the negotiation that was being done, as if it were ... I have pain, I have a heart ache when thinking about that period. This was the period ... I would say the hardest of my life where I have the impression that you had become like God; you have the power of life and death. Because when you select someone, he had a chance to live and the other was doomed to die, and it was hard! Sometimes we were confronted with the same family: a mother with a daughter in which case the mother had to renounce to give her child a chance to live. And it was very hard. It was sincerely the hardest periods of our action when it was necessary ... but we were obliged to proceed in that way, to explain to the people that with what we could mobilize, we could not satisfy everyone's needs ..."

The REVS + members selected as being a priority eligible for antiretroviral treatment were less than a dozen at the launch of this operation; thereafter, the number of "laureates" increases to 16, including individuals who were not active or without responsibility in the association, before doubling and then experiencing a continuous increase as the quantity of drugs increases. The shift from fellow associations' support to ARV delivery through ordering allowed REVS+ to have larger doses of drugs year after year and to significantly increase its care provision capacities through ARVT. According to its president, in June 2015, it provided ARV care for more than 1,200 infected people.

In just a few years these two NGOs went from the punctual assistance made possible thanks to the generosity and solidarity of foreign NGOs, to a real "policy" of access to ARV treatments, organized within their own health institutions, officially recognized as a medical centre (oasis center and CM 
REVS+). Very quickly, many other associations followed suit and proposed in their headquarters care for sick people who need ARVs ${ }^{22}$. These associative initiatives, experimented on a small scale, have, however, through their symbolic and practical value, contributed to inspiring the national policy of access to ARVs, based essentially on reducing costs in order to make them accessible to as many people as possible ${ }^{23}$.

\section{Essential Partners of the Health System}

The associations that are active in public arenas of fight against AIDS in Burkina have developed as time went by, a solid partnership with other institutional actors like the Government (at the national level) or the authorities in charge of the financing of the programs of fight against AIDS and other diseases with high epidemic potential (internationally).

The modes of associative commitment to the fight against this scourge of AIDS (beyond the two associations exemplified in this research) were expressed almost at the very moment of the construction of AIDS as a public issue [12]. They took different forms but will be a turning point at the end of the 1990s with the offer of counselling-screening and even more with the advent of treatment on ARVs. The social utility of NGOs/associations can be seen at different levels, such as the response to pandemics [16]. The associative and community world is now committed to the fight against the main pathologies (malaria, tuberculosis, HIV) in partnership with the health system of which it tends to become an essential ally. This reality appears in the words of this association leader who evokes the specific example of AIDS: "When you take, for example, the HIV-related concern, all the prevention- related issues, such as the

\footnotetext{
22 This is for example the case of ALAVI. This association asked its partners to support people already identified as HIV positive and monitored locally by doctors. When they needed to be on ARVs, ALAVI obtained from its partners stocks of medicines sent by DHL.

${ }^{23}$ Since January 2010, a government measure introduced free ARVs in Burkina Faso.
}

case of voluntary screening, our contribution as the associative world is more than $80 \%$ in the national results." (interview, coordinator of the Burkinabe Council of NGOs and Associations against HIV, Burkaso).

In their desire to offer services covering both prevention and care, sometimes the delivery of certain packages of activities is transformed into the exclusive field of intervention claimed and provided by associative actors. This occurs especially when there is a failure of public health services. These associative actors show strong measures to replace (or even supplant) professionals in the field. The community-based intervention is intended to move into the most remote localities (including hamlets) and domestic spaces, which is once again the prerogative of community-based organizations. This is especially true for awareness raising and screening, as evidenced by this testimony:

"For example, health workers do not have time or means for the screening. The means today is the community world that goes out and organizes screening campaigns... When we take the TB issue today, everything related to upstream awareness raising issues, referral, case detection, we have contributed a lot. So our contribution to improving the health of patients, when we consider the patients who are treated over six months, and when you see our rapport in terms of treatment compliance you see how patients are made to be observant because health facilities do not have these mean. It is at the community level that we can better act on these levers \{sensitization, lost sight of ...\} and then make the treatment of the patients better. I think that, here, the civil society has contributed much especially in the response to HIV. Today, Burkina comes among the best in terms results; if the AIDS prevalence has dropped significantly, it is because we have contributed a lot.” (Interview, Burkaso Coordinator).

The paramedical activity of associative actors can be deployed either within the organization (when it has its own health centre) or in the public health centre. In the 
latter case, the associative agents, as auxiliaries, support the health centres by providing various services on the spot: psychosocial permanence, pre and post screening counselling, animation of educational talks. This support to health workers in their daily work reflects the synergy of action that mobilizes in the same view, professional healthcare providers and community agents. The latter, regardless of their intervention field, have a sufficient knowledge and mastery of the "community" field (driving patients from hamlets to health centres for diagnosis and anti-tuberculosis treatment; visits to AIDS patients' homes, interventions in health centres, etc.).

The modes of commitment of the civilian world to the health field are seen not only through the implementation of specific and "proximity" activities, but also through its participation in the debates for the promotion of the rights of people infected by HIV. From this point of view, it has been able to set itself up repeatedly, as a real propositional force, able to challenge the public authorities, asking them, if necessary, to reconsider their policies to take more into account the specific needs of PLHIV (right to life, right to care, right to work, etc.). The example of free ARVs, officially implemented in Burkina Faso in January 2010, resulted from a long-term struggle during which NGOs/associations continued to exert strong pressure on the rulers with the view to obtain the actual translation of this right to concrete health action for PLHIV. With this double position, the associative organizations successively show constructive and claiming capacities. Consequently, their social utility lies in their involvement and multifaceted contributions to the progress of the struggle for the general interest, an interest intended for the whole society beyond that of the individuals and groups for whom they defend the cause [17].

\section{Conclusion}

This research was intended to understand the logic of action of Burkina Faso's HIV/AIDS associations, based on the experience of two of them. It was a matter of questioning not only the processes and the modalities of their rooting in the public space, but also the repertoires of action and intervention implemented to offer social and medical assistance to populations vulnerable to HIV infection. As such, the two associations with which we conducted our observations and surveys have many similarities both in their nature and in the philosophy that guides their actions. However, they have different processes, experiences and strategies in the specific area of providing services to their target populations. In order to make ARVs accessible to infected individuals, the two organizations, through their leaders, showed the same determination and determination to achieve their objectives. If on the AAS's side, the singular destiny of an infected official was the channel by which the members of the association, then the population have in turn acceded to the treatments, on the other hand for REVS+, it was by the way of institutional collaboration that hope was given. But above all, in both cases, the trigger will also come from the meeting with NGOs and associations of the North, who act both as models of reference (sharing their experiences) and providers of material assistance and funds to their counterparts in the South.

Thanks to its determination and the support received from international institutions, the world of association has been at the forefront of the response to HIV/AIDS when it came to offering credible and effective care, as attested by the example of ARVs. This early commitment was already seen in the field of prevention with the offer of voluntary counselling and screening, an activity also initiated for the first time in associations before spreading to the public sector [19]. The creation and rooting of associations in a given context is related to social demand. As for any organization of civil society, these organizations are most often created to respond to a need expressed in the society, moreover, when the field in question is insufficiently covered by the Government. 
Faced with these realities, associations are becoming more and more pressure forces against public authorities [20]. However, it is possible to say, in view of the dynamics in the field of the fight against AIDS, that these organizations of the civilian world are above all forces of proposal showing a real constructive capacity and dialogue [21]. They also claim recognition of their roles, which are at the same time social watch, detection and analysis of needs, mobilization of civil society, expertise or proposals for alternative solutions [18, 17]. This production of service for the population seems to be the leitmotif of these non-governmental stakeholders who act not against or instead of the Government, but with the Government, since their actions are part of a global framework and consensus defined by this authority. This should not make us forget, however, that conflicting processes can nevertheless contrast Government and associations with some choices and political decisions made by the public authorities [12].

However, despite their many positive actions, the AIDS control associations in Burkina Faso are characterized above all by their fragility. This fragility is due to the fact that they are largely dependent on public and external funds. With the net inflow of the financial contribution of bilateral and multilateral partners (following the "normalization” of AIDS) ${ }^{24}$, the Government of Burkina Faso, tends to become the main fund provider in the fight against AIDS in Burkina Faso. This announced reduction in the financial support to be redistributed forces associations to explore other alternative strategies to make up for this shortfall ${ }^{25}$. Anything, that definitely contributes to

\footnotetext{
${ }^{24}$ At present, AIDS is a chronic disease, and has even become a disease "like the others"; as a result, it does not drain as much money as when it posed a threat to humanity. In other words, AIDS would no longer be a priority for international donors today who are redirecting their financial flows to diseases such as malaria and tuberculosis.

${ }^{25}$ Many national associations and NGOs such as AAS, REVS +, ALAVI, have already embarked on this dynamic of diversification of their sources of funding. On top of that, they are developing income-generating activities for themselves; and finally they are launching themselves more and more into
}

redefining their roles and missions in the years is to come.

In spite of these uncertainties, the associations, thanks to their multiform actions and the strong legitimacy they are given, have contributed to giving a tangible reality to the idea of "health democracy". The right to health and treatment is posited as a social issue by these organizations of civil society in the name of social justice and equity.

\section{References}

[1] Eboko, F. 2013. De l'intime au politique. Modèles dissonants et régulation des politiques publiques. A partir de la lutte contre le sida en Afrique, mémoire d'HDR, IRD-INSERM, Aix-Marseille Université, p. 240.

[2] Pinell, P., ed. 2002. Une épidémie politique. La lutte contre le sida en France. 1981-1996, Paris: PUF, p. 415.

[3] Perelman, B. 2003. Les associations de lutte contre le sida à Ouagadougou. Contexte d'émergence, profils et pratiques, mémoire DESS. Paris: Ouagadougou, IEDES-IRD, p. 77.

[4] Gruénais, M.-E., ed. 1999. Organiser la lutte contre le sida: une étude comparative sur les rapports État/société civile en Afrique.Paris: Institut de recherche pour le développement.

[5] Eboko, F. 1999. "Introduction à la question du sida en Afrique. Politique publique et dynamiques sociales.” InPolitiques publiques du sida en Afrique, Travaux etdocuments, edited byKerouedan D., No. 61-62, Bordeaux, pp. 35-73.

[6] Eboko, F., Bourdier, F., and Broqua, C. 2011. Les Sudsface au sida. Quand lasociété civile se mobilise, Marseille, IRD, p. 398.

[7] Soubeiga, A. 2015. "De la maladie mortelle à la maladie chronique. Le sida perturbateur ou réformateur de la santé publique en Afrique?” Le journal des Sciences sociales 2 (12): 191-209.

[8] Duran, P. 1999. Penser l'action publique, Droit et société, vol. 27, MSH.

[9] Lascoumes, P. and Le Galès P., 2007. Sociologie de l'actionpublique, Paris A Colin, p. 126.

[10] Dourlens, C. 2010. L'action publique à l'épreuve de la fragilité normative, mémoire d'HDR, Université Jean Monnet, Saint-Etienne, p. 149.

[11] Musselin, C. 2005. “Sociologie de l'actionorganiséeet analyse des politiquespubliques :deuxapproches pour un même objet?” Revue française de science politique

the international competition market through calls for projects to diversify the opportunities to be financed. 
Case of AAS and REVS+ in Burkina Faso

55(1): 51-71.

[12] Soubeiga, A. 2016. Mobilisations associatives et reconfigurations de l'action publiquedans la lutte contre le sida au Burkina Faso,mémoire d'HDR, Université de Bordeaux, p. 273.

[13] Presentation document of REVS + and its activities.

[14] Laville, J.-L., and Sainsaulieu, R. 2013. L'association. Sociologie et économie, Paris, Fayard, p. 438.

[15] Cardin, H., and Messager, D. 2013. La Révolution sida, Paris: Odile Jacob, p. 218.

[16] Engels, X., Hély, M., Peyrin, A., Touvé, H., eds. 2006. De l'intérêt général à l'utilité sociale. La reconfiguration de l'action publique entre Etat, associations et participation citoyenne. Paris: l'Harmattan, p. 280.

[17] Moreau, M. 2006. "Les associations d'environnement en France: entre inérêt général et utilité sociale.” In De l'intérêt général à l'utilité sociale, edited by Engels et al.,
Paris: l'Harmattan, pp. 53-64.

[18] Jacob, S., and Genard, J.-L., eds. 2004. "L'Etat et les savoirs experts: la production cognitive en mutation." InExpertise et action publique, de l'Université de Bruxelles, pp. 7-12.

[19] Desclaux, A., and Raynaut, C. 1997. Le dépistage VIH et le conseil en Afrique au sud du Sahara. Paris, Karthala: Aspects médicaux et sociaux, p. 326.

[20] Ilboudo, D. 2010. "Recompositions contemporaines de l'action publique associative dans la lutte contre le VIH/sida: le cas du Burkina Faso." In Annales de l'Université de Ouagadougou, Série A, Vol. 010, pp. 179-207.

[21] Auclair, E., and Benjamin, I. 1993. "Développement de la vie associative du secteur environnement.” In Recherche Sociale, No. 127. 